\title{
INSTRUKCJE W KANONICZNYM PORZĄDKU PRAWNYM (KAN. 34 § 1-3 KPK)
}

\begin{abstract}
Streszczenie. Autor dokonał interpretacji kan. 34 § 1-3 KPK dotyczącego instrukcji. Z przeprowadzonych w tym artykule analiz wynika, iż współcześnie w nazewnictwie aktów o charakterze generalnym, wydawanych przez autorytety posiadające władzę wykonawczą, występuje duży chaos pojęciowy. Autor dowiódł, iż taki stan faktyczny wskazuje na to, iż zamiar ustawodawcy występujący w pracach kodyfikacyjnych, zmierzający do ujednolicenia nazewnictwa, spełzł na niczym. W jego przekonaniu zapis ujęty w kan. 34 KPK pozostaje zapisem wyłącznie na papierze. Definicja instrukcji skodyfikowana w kan. $34 \S 1 \mathrm{KPK}$ w praktyce stanowi bowiem jedynie punkt odniesienia, pozwalający sklasyfikować wydawane przez władzę wykonawczą akty o charakterze generalnym.

Slowa kluczowe: instrukcja, kanoniczny porządek prawny, akty prawne o charakterze generalnym.
\end{abstract}

\section{WPROWADZENIE}

Tytuł III Księgi I Kodeksu prawa kanonicznego poświęconej „Normom ogólnym” zatytułowano „Dekrety ogólne oraz instrukcje”. W kan. 34 § 1-3 KPK prawodawca odniósł się do kategorii aktów, jakimi są instrukcje, stanowiąc:

$\S 1$. Instrukcje, które mianowicie wyjaśniają przepisy ustaw oraz rozwijają i określają racje, które należy uwzględnić przy ich zachowaniu, są dane na użytek tych, którzy mają się troszczyć o wprowadzenie ustaw w życie i obowiązują ich w wykonywaniu ustaw. Wydają je zgodnie z prawem w granicach swych kompetencji ci, którzy posiadają władzę wykonawczą.

$\S 2$. Postanowienia instrukcji nie zmieniają ustaw. Jeśli zaś któreś z nich nie dadzą się pogodzić z przepisami ustaw, są pozbawione wszelkiej mocy.

$\S 3$. Instrukcje tracą moc nie tylko przez odwołanie wyraźne lub pośrednie przez kompetentną władzę, która je wydała, lub wyższą, lecz także przez wygaśnięcie ustawy, dla której wyjaśnienia czy wprowadzenia jej w życie, zostały wydane.

Zapis kan. 34 § 1-3 KPK jest nowy. W kodyfikacji pio-benedyktyńskiej nie występowała bowiem tego typu regulacja. W literaturze wśród źródeł tego kanonu w pierwszym rzędzie wskazuje się na wydane w dniu 15 września 1917 r. przez papieża Benedykta XV motu proprio Cum iuris canonici. W n. 2 tego dokumentu zawarto definicję instrukcji, stwierdzając, iż jej celem jest wyjaśnianie

* Uniwersytet Kardynała Stefana Wyszyńskiego w Warszawie, Wydział Prawa Kanonicznego, Katedra Teorii i Norm Ogólnych Prawa Kanonicznego, ginter.dzierzon@gmail.com. 
ustaw i dążenie do uzyskania ich większej skuteczności (Benedictus XV 1917, 484; Mazzia 2010, 113; Sobański 2003, 93).

Według M. Mazzia bezpośrednim źródłem kan. 34 § 1 KPK jest opublikowana w dniu 25 marca 1922 r. przez Kongregację ds. Zakonnych Instrukcja Doceatur quae decreta, adresowana do moderatorów generalnych zakonów o ślubach prostych (Sacra Congregatio de Religiosis 1922, 278-286; Mazzia 2010, 114). Ponadto wykazała ona, że pozostałe paragrafy kan. 34 KPK nie posiadają źródel; oznacza to, iż te zapisy są zupełnie nowe (Mazzia 2010, 114).

Rozpoczynając prezentację problemu ujętego w tytule opracowania, należy skonstatować, iż w klasyfikacji aktów prawnych wydanych pod rządami Kodeksu prawa kanonicznego z 1917 r. występowało pewne nieuporządkowanie. Dykasterie Kurii Rzymskiej oprócz nazwy „instrukcja” posługiwały się bowiem również innymi pojęciami, takimi jak ordinationes czy normae; termin ,instrukcja” odnoszono też do dekretów ogólnych posiadających charakter ustaw (Socha 1985, ad 34,1; Sobański 2003, 93). H. Socha w komentarzu do kan. 34 KPK wyliczył szereg instrukcji Kongregacji Kurii Rzymskiej, których następstwem była zmiana ówczesnego prawa (Socha 1985, ad 34,1). Przywołał on m.in. wydaną w dniu 15 sierpnia 1935 r. przez Kongregację ds. Dyscypliny Sakramentów Instructio servanda a tribunalis dioecesanis in pertractanda causis de nullitate matrimonium, a także opublikowaną $\mathrm{w}$ dniu 18 marca 1966 r. przez Kongregację Doktryny Wiary Instructio de matrimoniis mixtis.

Wobec takiego stanu faktycznego celem prac Komisji Kodyfikacyjnej miało stać się uporządkowanie tego stanu rzeczy. Dlatego też w nowym kodeksie znalazł się kan. 34 § 1-3 KPK.

\section{DEFINICJA INSTRUKCJI (KAN. 34 § 1 KPK)}

W komentarzu opracowanym przez V. De Paolisa i A. D'Aurię stwierdzono, iż prawodawca, definiując tak ważki akt dla prawa administracyjnego, pragnął nadać temu pojęciu ściśle określone znaczenie, odróżniając je od innych znaczeń funkcjonujących w praktyce (De Paolis, D'Auria 2008, 197). Zdaniem J. Garcii Martína definicja instrukcji ujęta w kan. 34 § 1 KPK jest analogiczna do tej, która występuje w kan. 31 § 1 KPK dotyczącym ogólnych dekretów wykonawczych (García Martín 1999, 172; Dzierżon 2005, 189-199). Twierdzi on, że wypracowanie takiej definicji było konieczne ze względu na fakt, iż do promulgacji Kodeksu z 1983 r. w kanonicznym porządku prawnym $\mathrm{w}$ tym względzie panował chaos pojęciowy, ponieważ - jak już zasygnalizowano - kongregacje Kurii Rzymskiej, posiłkując się pojęciem instrukcji, wydawały również akty o charakterze ustaw (Pontificia Commissio Codici Iuris Canonici Recognoscendo 1988, 102; García Martín 1999, 172).

Z zapisu kan. 34 § $1 \mathrm{KPK}$ wynika, że terminu ,instrukcja” nie należy utożsamiać z pojęciem ustawy czy dekretu ogólnego. Wprowadzając ten termin do obiegu, zrealizowano tym sposobem postulat wyrażony podczas prac kodyfikacyjnych, 
aby ustaw nie wydawać w formie instrukcji (,sub forma Instructionum ferri non possunt leges") (Mazzia 2010, 116; Chiappetta 1996, 88; Pontificia Commissio Codici Iuris Canonici Recognoscendo 1982, 136).

Odnosząc się do prezentowanej definicji, Mazzia wyróżniła w niej dwa komponenty: komponent ekspozycyjny wiążący się z wyjaśnianiem przepisów ustaw oraz komponent dyspozycyjny związany z procedowaniem wynikającym z realizacji postanowień ustaw (Mazzia 2010, 115). Rozwijając tę myśl, autorka przywołała zwrot występujący w kan. 34 § 2 KPK „Instructionum ordinationes legibus non derogant”, wskazując, iż pojawienie się terminu ordinationes oznacza, że ten akt prawny powinien zawierać precyzyjne normy mające służyć pomocą we wprowadzeniu ustawy w życie (tamże) ${ }^{1}$.

Należy dodać, że cechą charakterystyczną instrukcji, podobnie jak innych aktów, o których mowa w Tytule III Księgi I „Dekrety ogólne i instrukcje”, jest ich abstrakcyjność (Miras, Canosa, Baura 2001, 95). Idzie bowiem o akty administracyjne o charakterze generalnym (Chiappetta 1996, 88).

\section{CELE INSTRUKCJI}

W myśl kan. 34 § 1 KPK wydawaniu instrukcji przyświecają dwa cele: wyjaśnienie przepisów ustaw oraz rozwijanie i określenie racji, które należy uwzględnić przy ich zachowaniu (Ciáurriz 1996, 496). Pierwszy z wymienionych celów ma charakter hermeneutyczny (Labandeira 1994, 251). Komentatorzy są zgodni co do tego, iż normatywny termin declarare oznacza interpretację ustawy o charakterze praktycznym. W sensie negatywnym nie idzie więc o interpretację autentyczną (Socha 1985, ad 34,5) czy też o interpretację doktrynalną (De Paolis, D'Auria 2008, 198).

Natomiast drugi z celów wiąże się z określeniem procedury, jaką należy zachować z wprowadzeniem ustawy w życie (tamże). Jak napisała Mazzia, instrukcje zawierają ordinationes, czyli normy mające służyć aktualizacji ustawy (Mazzia 2010, 115). Przy tym należy zauważyć, iż omawiana kategoria aktu różni się od dekretu generalnego wykonawczego, gdyż w akcie tym określa się sposoby zachowania ustawy (kan. $31 \S 1,32 \mathrm{KPK})$ (tamże).

\section{WLADZA KOMPETENTNA DO WYDANIA INSTRUKCJI}

Kompetentny do wydania instrukcji jest autorytet posiadający władzę wykonawczą (kan. 34 § $1 \mathrm{KPK}$ ), a ściślej - idzie o władzę administracyjną w granicach swych kompetencji (Miras, Canosa, Baura 2001, 95-96). W tym wypadku nie ma

${ }^{1}$ „Accanto a questi primi elementi di definizione occorre considerare la specificazione contenuta nel paragrafo 2, laddove si dice »Instructionum ordinationes legibus non derogant «, e quindi si puó aggiungere che l'istruzione puó commetere ordinationes, in altre parole norme precise per l'attuazione della legge". 
znaczenia, czy osoba dysponująca władzą wykonawczą posiada również władzę ustawodawczą (tamże).

Ze względu na zakres władzy, która może mieć zarówno charakter uniwersalny, jak i partykularny, w kanonicznym porządku prawnym są wydawane instrukcje o charakterze powszechnym (instructiones universales) oraz instrukcje o charakterze partykularnym (instruciones particulares) (Socha 1985, ad 34,4). Zdaniem Sochy dyspozycja kan. 34 § KPK odnosi się również do uprawnień Konferencji Episkopatu, może ona bowiem wydawać tego typu akty (tamże). W skali Kościoła powszechnego wydają je Kongregacje Kurii Rzymskiej (Ciáurriz 2012, 676).

W prezentowanym wątku nie można pominąć faktu, iż na podstawie zasady hierarchii legalności wydane instrukcje nie muszą być aprobowane przez tych, którzy posiadają władzę ustawodawczą (García Martín 1999, 173).

\section{ADRESACI INSTRUKCJI}

Z treści kan. $34 \S 1$ KPK wynika, iż adresatami instrukcji są ci, którzy mają troszczyć się o wprowadzenie ustaw w życie (Mazzia 2010, 116). Zasadniczo więc dyrektywy zawarte w tych aktach nie odnoszą się bezpośrednio do adresatów ustaw (Socha 1985, ad 34,6). Mając na uwadze machanizm aplikacji, komentatorzy podkreślają, iż instrukcje różnią się od ogólnych dekretów wykonawczych tym, że mają charakter wewnętrzny (Chiappetta 1996, 88). W komentarzu do kan. 34 KPK M. J. Ciáurriz mówi o dyspozycjach generalnych wewnętrznych organizacji kościelnej (Ciáurriz 2012, 676) ${ }^{2}$. Taki charakter instrukcji wynika z faktu, iż skierowane są one do tych, którzy mają zabiegać o wdrożenie ustaw życie; ogólne dekrety wykonawcze zaś obowiązują tych, którzy podlegają ustawom (Bernàrdez Cantón 2001, 111). Komentatorzy podkreślają, że ponieważ instrukcja nie wprowadza żadnego nowego prawa przedmiotowego, nie wymaga promulgacji (Socha 1985, ad 37,7; Wächter 2008, 472). Brak promulgacji nie oznacza jednak, że ten akt prawny nie powinien być opublikowany. Trzeba podkreślić, że jest to konieczne, gdyż jego adresaci powinni zapoznać się z jego treścią. Sposób publikacji zależy od autorytetu podejmującego decyzję w tej materii (De Paolis, D’Auria 2008, 198). Poruszając ten problem, J. Miras, J. Canosa i E. Baura mówią o promulgacji wyłącznie dla adresatów (promulgación solo para los destinatarios) (Miras, Canosa, Baura 2001, 95). Kanoniści ci w swym podręczniku rozpatrzyli jeszcze jedną hipotezę, mianowicie zwrócili uwagę, że jeśli instrukcja zawierałaby przepisy „zewnętrzne” dla administracji, to w takiej sytuacji konieczne byłoby ich promulgowanie (tamże) ${ }^{3}$.

2 „Las instrucciones, en efecto, son disposiciones generales internas de la organización ecclesiástica, que van dirigidas a aquellos autoridates o titulares de oficios a quien compete cuidar de la ejecución de las leyes".

3 „Puesto que las instrucciones no están dirigidas a todos destinatarios de la ley, no necesitan promulgadas: basta que lleguen a conocimieto de las destinatarios obligados (es decir, se »promulguen 


\section{WALOR PRAWNY INSTRUKCJI}

Walor prawny instrukcji określają ustawy, do których się one odnoszą (Mazzia 2010, 117). Twierdzenie to znajduje umocowanie w zapisie kan. 34 § KPK, zgodnie z którym „Postanowienia instrukcji nie zmieniają ustaw”. Oznacza to więc, iż te akty prawne nie mogą być przeciwne ustawom (Socha 1985, ad 34,8; Horta Espinoza 2007, 49). A zatem w tych treściach, których nie da się ich uzgodnić z ustawą, są one pozbawione wszelkiej mocy (Listl 1983, 85; Mazzia 2010, 117).

\section{USTANIE INSTRUKCJI (KAN. 34 § 3 KPK)}

Z brzmienia kan. 34 § 3 KPK wynika, iż instrukcja może ustać na dwa sposoby: po pierwsze, przez odwołanie kompetentnej władzy oraz, po drugie, przez wygaśnięcie ustawy. Należy zauważyć, iż rozwiązania te są analogiczne do tych, które dotyczą odwołania ogólnych dekretów wykonawczych (kan. 33 § KPK).

$\mathrm{W}$ doktrynie pierwszą $\mathrm{z}$ form określa się mianem odwołania zewnętrznego (ab extrinseco). Może ono zostać dokonane $\mathrm{w}$ formie wyraźnej lub $\mathrm{w}$ formie pośredniej (implicite). Pierwsza postać odwołania ma miejsce w przypadku wydania dokumentu zawierającego treści odwołujące; odwołanie implicite natomiast odbywa się poprzez wydanie nowej instrukcji przeciwnej tej, która obecnie funkcjonuje (Mazzia 2010, 118).

Ponadto instrukcja może zostać uchylona przez wygaśnięcie ustawy (kan. 20 KPK) (Dzierżon 2013, 170-176), gdyż tym sposobem przestaje istnieć przyczyna finalna, dla której została ona wydana.

Kończąc ten passus, należy zauważyć, iż w zapisie kan. 34 § 3 KPK nie znalazło się ostatnie zdanie kan. $33 \S 2 \mathrm{KPK}$ : „Nie wygasają natomiast z ustaniem władzy wydającego, chyba że co innego wyraźnie zastrzeżono" (Vela 1993, 331; Mazzia 2010, 118).

\section{PODSUMOWANIE}

Z przeprowadzonych analiz wynika, iż pojęcie „instrukcja” występujące w kan. $34 \S 1$ KPK jest nowe w kodeksie; nie jest natomiast nowe w praktyce, gdyż dykasterie Kurii Rzymskiej przed promulgacją Kodeksu z 1983 r. wydawały tego typu akty prawne (Mazzia, 2010, 121). Badając obecny stan prawny, należy jednak zauważyć, iż zamierzenie ustawodawcy podjęte podczas prac kodyfikacyjnych, zmierzające do uporządkowania kwestii nazewnictwa w obszarze aktów

solo para los destinatarios«. Si contuviese alguna disposición »externa« a la Administración, la instrucción dejaría, de ser tal y, por la norma valida, tendría, obviamente, que ser promulgada”. 
o charakterze generalnym, nie do końca się powiodło. Jak piszą komentatorzy, w obowiązującym kodeksie nie wyklucza się możliwości wprowadzenia instrukcji o charakterze ustawy. Na potwierdzenie tej tezy w piśmiennictwie przytacza się kan. 1276 § 2 KPK, w którym postanowiono: „uwzględniając prawa, prawne zwyczaje oraz okoliczności, ordynariusze powinni poprzez wydanie szczegółowych instrukcji [...] starać się o uregulowanie zarządu dóbr kościelnych" (Socha 1985, ad 34,2). Ponadto, w obowiązującej kodyfikacji w obszarze prawa procesowego funkcjonuje inne pojęcie, jakim jest ,instrukcja sprawy” (instructio causae) (kan. $1699 \S 1,1700,1702,1704,1705 \S 2,1742$ § 1, 1745, n. 2 KPK) (tamże).

Komentatorzy zwracają też uwagę, że już po wejściu w życie Kodeksu z 1983 r. Stolica Apostolska wydała dokumenty, w których operuje ona terminem „,instrukcja”, ale nie w rozumieniu kan. 34 § 1 KPK. I tak, 13 sierpnia 1997 r. kilka dykasterii Kurii Rzymskiej opublikowało „Instrukcję o niektórych kwestiach dotyczących współpracy wiernych świeckich w ministerialnej posłudze kapłanów" (Opoka 2016). Ten akt prawny ma charakter dekretu ogólnego (kan. 30 KPK), który uzyskał aprobatę papieską w dniu 15 sierpnia 1997 r. (Miras, Canosa, Baura 2001, 95) .

We współczesnej doktrynie istnieją poważne trudności z klasyfikacją systemową Instrukcji Dignitas connubii, wydanej w 2005 r. przez Papieską Komisję ds. Tekstów Prawnych (Pontificium Consilium de Legum Textibus 2005). Większość kanonistów utrzymuje, że ma ona charakter ogólnego dekretu wykonawczego (Daneels 2013, 260).

Również w nazewnictwie dokumentów Konferencji Episkopatu Polski występuje pewne zamieszanie w tym względzie. W dniu 14 marca 1987 r. wydała ona „Instrukcję w sprawie duszpasterstwa małżeństw o różnej przynależności kościelnej” (KKBiDS 2016). Ten akt prawny nie jest jednak instrukcją w znaczeniu kan. 34 § 1 KPK, lecz ogólnym dekretem wykonawczym (kan. 31-33 KPK). Na marginesie należy dodać, że analogiczne dokumenty Konferencji Episkopatu Włoch i Hiszpanii noszą nazwę dekretu (Conferenza Episcopale Italiana 1990, kol. 1313-1340; Conferencia Episcopal Española 1984, 118-120).

Taka rzeczywistość niesie ze sobą poważne trudności w określeniu waloru niektórych aktów prawnych funkcjonujących w kanonicznym porządku prawnym. Trzeba podkreślić, iż oceniając walor aktu, nie można wyłącznie brać pod uwagę jego tytułu, istotna jest bowiem jego treść. W przypadku instrukcji, o których

${ }^{4}$ „Aun el CIC hay reservado la palabra »instrucción« para el tipo de norma [...] hay que tener en cuenta lo ya adveritido anteriormente, o sea, que las normas pueden darse bajo nombre muy distintos, siguiendo criterios más o menos tradicionales de canceleria. Así, por ejemplo, después de entrada en vigor del CIC, se ha promulgato el 15 de agosto de 1997, con la aprobación especifica del Papa una importante »Instrucción « sobre algunas cuestiones relativas a la colaboración de los fieles laicos en el misterio de los sacerdotes, cuya autor son dicasterios. Indudablmente, se trata en realidad de decreto legsilativo de los del c. 30 con fuerza de ley, en virtud de la aprobación especifica, y no de una instrucción del c. 34 [...]". 
traktuje kan. $34 \S 1$ KPK, istotne są odniesienie aktu do obowiązującej ustawy oraz adresat aktu.

Występujący obecnie chaos pojęciowy jest podobny do tego, jaki istniał przed wejściem w życie Kodeksu z 1983 r. Potęgowany jest jeszcze tym, że w kan. 33 $\S 1$ KPK odnoszącym się do ogólnych dekretów wykonawczych stworzono możliwość wydania tych aktów pod inną nazwą.

Ukazany stan faktyczny wskazuje na to, że zamiar ustawodawcy zadeklarowany w pracach kodyfikacyjnych, polegający na ujednoliceniu nazewnictwa, spełzł na niczym. Zapis ujęty w kan. 34 KPK pozostaje zapisem wyłącznie na papierze. Definicja instrukcji skodyfikowana w kan. $34 \S 1 \mathrm{KPK}$ w praktyce stanowi bowiem jedynie punkt odniesienia, pozwalający sklasyfikować wydawane przez władzę wykonawczą akty o charakterze generalnym.

\section{BIBLIOGRAFIA}

\section{Źródla}

Benedictus XV. 1917. „Motu proprio Cum iuris canonici” (15.09.1917). Acta Apostolicae Sedis 9: 483-486.

„Codex Iuris Canonici auctoritate Ioannis Pauli PP. II promulgatus” (25.01.1983). 1983. Acta Apostolicae Sedis 75 (pars II): 1-317. Tekst polski: Kodeks Prawa Kanonicznego. 1984. Przekład polski zatwierdzony przez Konferencję Episkopatu. Poznań: Pallottinum.

Conferencia Episcopal Española. 1984. „Decreto general sobre normas complementarias al nuevo Código de Derecho Canónico" (5.07.1984). Bioletín Oficial de la Conferencia Episcopal Española 3: 118-120.

Conferenza Episcopale Italiana. 1990. „Il decreto generale sul matrimonio canonico” (5.11.1990). Enchiridion CEI 4: 1313-1340.

Pontificia Commissio Codici Iuris Canonici Recognoscendo. 1982. „Schema Codicis Iuris Canonici". Communicationes 14: 122-230.

Pontificia Commissio Codici Iuris Canonici Recognoscendo. 1988. „Disceptatio De instructionibus et Decretis". Communicationes 20: 100-109.

Pontificium Consilium de Legum Textibus. 2005. Instructio „Dignitas connubii” (25.01.2005). Città del Vaticano: Libreria Editrice Vaticana.

Sacra Congregatio Pro Doctrina Fidei. 1966. „Instructio de matrimoniis mixtis” (18.03.1966). Acta Apostolicae Sedis 58: 235-239.

Sacra Congregatio de Disciplina Sacramentorum. 1936. „Instructio servanda a tribubalis dioecesanis in pertractanda causis de nullitate matrimonium" (15.08.1935). Acta Apostolicae Sedis 28: 313-361.

Sacra Congregatio de Religiosis. 1922. „Instructio Doceatur quae Ducreta” (22.03.1922). Acta Apostolicae Sedis 14: 278-286.

\section{Literatura}

Bernàrdez Cantón, Alberto. 2001. Parte general de Derecho Canónico, Madrid: Tecnos.

Ciáurriz, Maria Jose. 1996. „Comentario al can. 34 CIC”. W Comentario exegético al Código de Derecho Canónico. Red. Angel Marzoa, Jorge Miras, Rafael Rodríguez-Ocaña. T. 1. 496-497. Pamplona: Universidad de Navarra. 
Ciáurriz, Maria Jose. 2012. „Instrucción”. W Diccionario general de Derecho Canónico. Red. Jorge Otaduy, Antonio Vianna, Joaquin Sedano. T. 4. 674-678. Pamplona: Universidad de Navarra.

Chiappetta, Luigi. 1996. Il Codice di Diritto Canonico. Commento giuridico-pastorale. Roma: Dehoniane.

Daneels, Frans. 2013. „Presentazione dell'Istruzione Dignitas connubii”. W Norme procedurali canoniche commentate. Red. Massimo del Pozzo, Joaquin Llobell, Jesus Miñambres. 260267. Roma: Coletti a San Pietro.

De Paolis, Velasio, Andrea D’Auria. 2008. Le Norme Generali. Commento al Codice di Diritto Canonico. Libro primo. Città del Vaticano: Urbaniana University Press.

Dzierżon, Ginter. 2005. „Ogólne dekrety wykonawcze w kanonicznym porządku prawnym”. Forum Iuridicum 4: 189-199.

Dzierżon, Ginter. 2008. Ewolucja doktryny oraz dyscypliny dotyczących przeszkody różności religii w kanonicznym porzadku prawnym. Warszawa: Wydawnictwo Uniwersytetu Kardynała Stefana Wyszyńskiego.

Dzierżon, Ginter. 2013. „Abrogazione esteriore della legge ecclesiatica (can. 20-21 CIC)”. W „Quod iustum est et aequum”. Scritti in onore del Cardinale Zenone Grocholewski per il cinquantesimo di sacerdozio. Red. Marek Jędraszewski, Jan Słowiński. 170-176. Poznań: Uniwersytet Poznański, Wydział Teologiczny.

García Martín, Jóse 1999. Le norme generali del Codex Iuris Canonici. Roma: Ediurcla.

Horta Espinoza, Jorge. 2007. Una legge fatta a misura dell'uomo. Introduzione ai libri I e II del Codice di Diritto Canonico, Roma: Antonianum.

Labandeira, Eduardo. 1994. Trattato di diritto amministrativo canonico, Milano: Giuffrè.

Listl, Joseph. 1983. „Die Rechtsnormen”. W Handbuch des katholischen Kirchenrecht. Red. Joseph Listl, Hubert Müller, Heribert Schmitz. 81-98. Regensburg: Verlag Friedrich Pustet.

Mazzia, Maria Maddalena. 2010. Gli atti amministrativi generali nel Codice di Diritto Canonico. Roma: LAS.

Miras, Jorge, Javier Canosa, Eduardo Baura. 2001. Compendio de derecho administrativo canónico. Pamplona: EUNSA.

Sobański, Remigiusz. 2003. „Komentarz do kan. 34 KPK”. W: Komentarz do Kodeksu Prawa Kanonicznego. Red. Józef Krukowski, Remigiusz Sobański. T. 1. 92-93. Poznań: Pallottinum.

Socha, Hubert. 1985. „Allgemeine Normen”. W Münsterischer Kommentar zum Codex Iuris Canonici. Red. Klaus Lüdicke. T. 1. Ad 34. Essen: Ludgerus Verlag.

Vela, Luis. 1993. „Decreto generale e istruzione”. W Nuovo dizionario di diritto canonico. Red. Carlos Corral Salvador, Velasio De Paolis, Gianfranco Ghirlanda. 330-331. San Paolo: Cinisello Balsamo.

Wächter, Lothar. 2008. „Instrucción”. W Diccionario enciclopédico de Derecho Canónico. Red. Stephan Haering, Heribert Schmitz. 472. Barcelona: Herder.

\section{Strony internetowe}

Komisja Kultu Bożego i Dyscypliny Sakramentów (KKBiDS). 2016. Instrukcja Episkopatu Polski w sprawie duszpasterstwa matżeństw o różnej przynależności kościelnej (14 marca 1987 r.). http://www.kkbids.episkopat.pl/?id=235 [dostęp 7.03.2016].

Opoka. 2016. Instrukcja o niektórych kwestiach dotyczących wspótpracy wiernych świeckich w ministerialnej postudze kapłanów (15 sierpnia 1997 r.). http://www.opoka.org./bibliotek/W/WR/ kongregacje/swieccy_kapl_02htlm [dostęp 5.03.2016]. 
pr. Ginter Dzierżon

\title{
INSTRUCTIONS BY CANON LAW SYSTEM (CAN. 34 § 1-3 CCL)
}

\begin{abstract}
The author presents an interpretation of can. $34 \S 1-3$ CCL concerning instructions. The analyses show that today names of general measures issued by authorities having the executive power present a big conceptual chaos. The author has proven that the facts indicate that the intention of the legislature in the work of codification aiming to standardize the names misfired. In his opinion, the norm included in canon. 34 CCL remains only a written record because a definition of instructions codified in canon. $34 \S 1$ of the CCL is in practice the only point of reference which allows classifying general application acts issued by the executive power.
\end{abstract}

Keywords: instruction, canonical law, legal acts of a general nature. 